This item was submitted to Loughborough's Research Repository by the author.

Items in Figshare are protected by copyright, with all rights reserved, unless otherwise indicated.

\title{
Discourse analysis and conversation analysis
}

PLEASE CITE THE PUBLISHED VERSION

PUBLISHER

Sage / @ Charles Antaki

VERSION

AM (Accepted Manuscript)

LICENCE

CC BY-NC-ND 4.0

REPOSITORY RECORD

Antaki, Charles. 2019. "Discourse Analysis and Conversation Analysis". figshare. https://hdl.handle.net/2134/5435. 
This item was submitted to Loughborough's Institutional Repository (https://dspace.lboro.ac.uk/) by the author and is made available under the following Creative Commons Licence conditions.

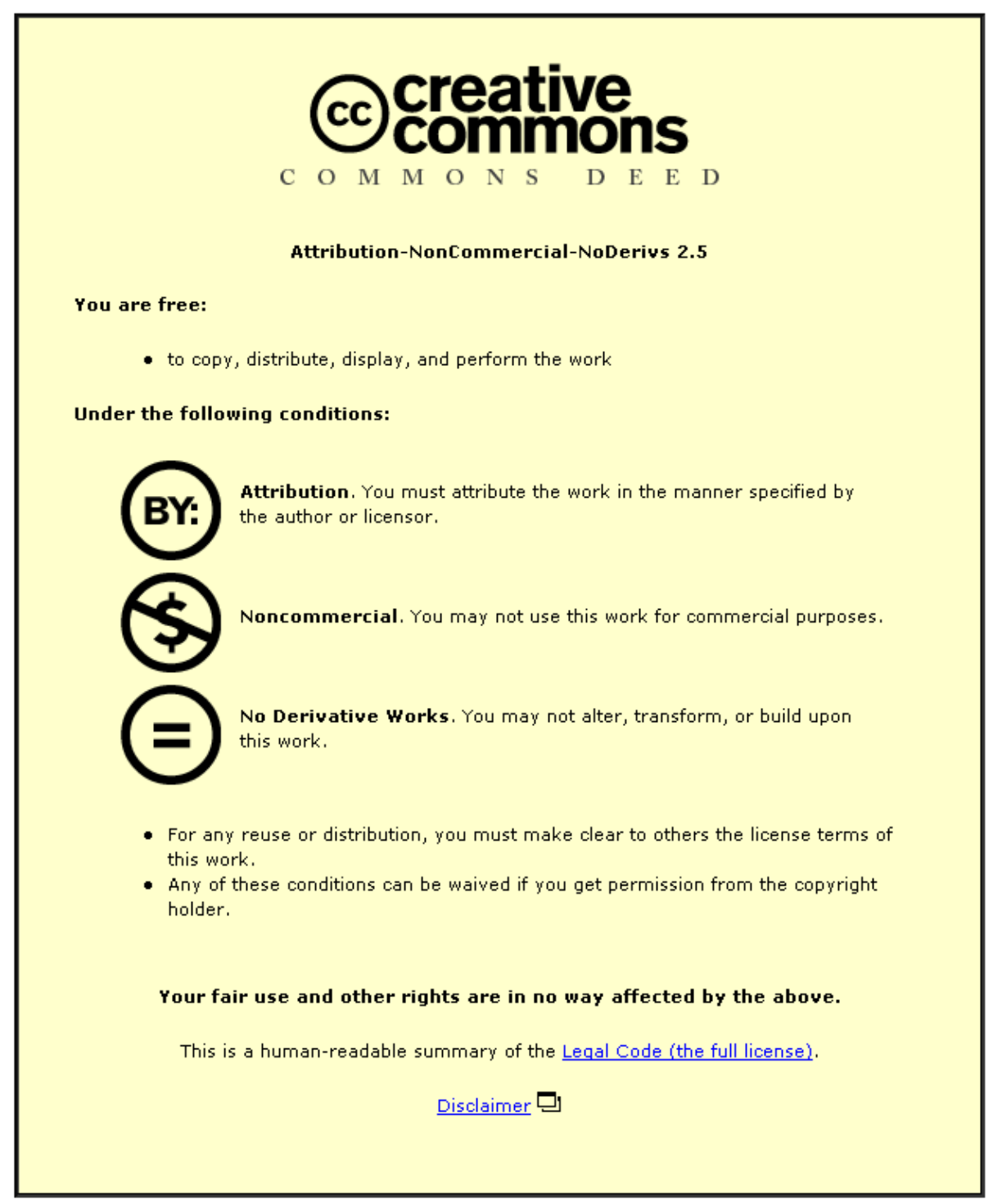

For the full text of this licence, please go to: http://creativecommons.org/licenses/by-nc-nd/2.5/ 


\title{
Analysing Discourse
}

\author{
Charles Antaki \\ Discourse and Rhetoric Group \\ Department of Social Sciences \\ Loughborough University \\ Loughborough LE11 3TU \\ England \\ c.antaki@Lboro.ac.uk
}

In: Pertti Alasuutari, Len Bickman, \& Julia Brannen (eds) Handbook of Social Research Methods. London: Sage (2009). 


\section{$\underline{\text { Analysing Discourse }}$}

"Discourse" means what people say or write. Scholars might want to look into what people say or write for many reasons: and their particular reason will play a large part in deciding just what sort of saying and writing they choose to study, and what methods they use to do so.

Students of history, cultural and media studies, and politics, among other disciplines, will want at times to identify a "discourse" as a collection of metaphors, allusions, images, historical references and so on that populate some cultural phenomenon (the discourse of modernity, for example, or the discourse of cyberculture, or the discourse of Human Resource Management; all current scholarly projects). That way of looking at discourse is more static than those I review in this chapter, where discourse is taken to be social action made visible in language. The sort of discourse analyst I talk about in this chapter is a social scientist: she or he sees discourse as an organisation of talk or text that does something, in the broad social world, or in the immediate interaction, or in both.

What kind of social action? Different ones, according to the interests of the analyst. The familiar way of setting out this difference is to range the interests from global to local. As we shall see later on, this distinction is itself a matter of dispute. But for the moment let us keep with it. At the more global end, discourse analysts can be interested in actions at the overarching level of social regulation, expressed though official and unofficial discourses like laws, media coverage or advertising texts; actions that have their effect not just in what is explicitly said, but what the analyst finds left unsaid. At that level, those doing the action (and those suffering it) may be classes of people, or 'society' in general. At the local end, the analyst might be interested in discourse that acts at the level of interaction, through conversationalists' activities, realised in the allocation, organisation and internal design of turns at talk. Here, doers and sufferers are visible in the scene.

$\underline{\text { Methods }}$ 
There is no lack of methods available to discourse analysts once they have decided where their interests lie. Since the "linguistic turn" in the social sciences of the nineteen seventies, qualitative methods textbooks have laid out an increasingly varied menu of discourse analytic methods, which have over the years moved from novel and marginal to familiar and central. Picking a method among these is apparently straightforward, once analysts have a clear idea of what interests them. In table 1, I range interests alongside appropriate methods.

Table 1 around here 
Table 1: Discourse analytic methods and data according to researchers' interests

\begin{tabular}{|l|l|l|}
\hline $\begin{array}{l}\text { what actions are to be } \\
\text { revealed }\end{array}$ & candidate theory/method & typical data \\
\hline Personal meaning-making & $\begin{array}{l}\text { Narrative Analysis, } \\
\text { Interpretative } \\
\text { Phenomenological Analysis }\end{array}$ & $\begin{array}{l}\text { interviews, diaries, } \\
\text { autobiographies, stories }\end{array}$ \\
\hline $\begin{array}{l}\text { Imposing and managing } \\
\text { frames of meaning and } \\
\text { identities }\end{array}$ & $\begin{array}{l}\text { Interactional } \\
\text { Sociolinguistics, } \\
\text { Ethnography of speaking }\end{array}$ & $\begin{array}{l}\text { audio and video recordings, } \\
\text { ethnographic observations }\end{array}$ \\
\hline $\begin{array}{l}\text { Accomplishing interactional } \\
\text { life in real time }\end{array}$ & Conversation Analysis & audio and video recordings \\
\hline $\begin{array}{l}\text { Displaying and deploying } \\
\text { psychological states; } \\
\text { describing the world and } \\
\text { promoting interests }\end{array}$ & Discursive Psychology & $\begin{array}{l}\text { audio and video recordings; } \\
\text { texts }\end{array}$ \\
\hline $\begin{array}{l}\text { Constituting and } \\
\text { representing culture and } \\
\text { society }\end{array}$ & $\begin{array}{l}\text { [Generic] Discourse } \\
\text { Analysis }\end{array}$ & texts, interviews \\
\hline $\begin{array}{l}\text { Constituting and regulating } \\
\text { the social and the political } \\
\text { world; the operation of } \\
\text { power }\end{array}$ & Critical Discourse Analysis & $\begin{array}{l}\text { official and unofficial texts; } \\
\text { speeches; media accounts } \\
\text { and representations; } \\
\text { interviews }\end{array}$ \\
\hline
\end{tabular}


Students of discourse analysis will recognise that the column headings in Table 1 should only be used as a convenience, because I have pretended that one can just start with a simple notion of 'what actions are to be revealed', list them, then read off the corresponding theory, method and data. In fact, of course, theory and method have a large say in calling something an 'action' in the first place, and what counts as evidence for that action; so these three solid apparently columns are better thought of as fuzzy threads twined around each other. Indeed, not even the rows are discrete; they too are harder to separate than the simple table suggests. All that will become clearer as we see examples of discourse analytic work in practice.

\section{Four core features of Discourse Analysis}

The table above shows a variety of named discourse analytic methods, but I have reserved an entry for unadorned "discourse analysis". That is useful for two reasons: it prompts us to ask what the core features are that makes something recognisable as discourse analysis, and reminds us that many scholars are happy to use just these features without committing themselves to one or other specific variant.

The four core features of any discourse analysis are these:

- the talk or text is to be naturally found (in the sense of not invented, as it might be in psycholinguistics, pragmatics or linguistic philosophy; some analysts admit interview data into this natural category, while others do not);

- the words are to be understood in their co-text at least, and their more distant context if doing so can be defended;

- the analyst is to be sensitive to the words' non-literal meaning or force;

- the analyst is to reveal the social actions and consequences achieved by the words' use - as enjoyed by those responsible for the words, and suffered by their addressees, or the world at large.

Before I give an account of some specific examples of discrete sorts of discourse analysis, it would be as well to recall that many social scientists find a serviceable use for what we might call 'generic' discourse analysis. This is work done without a strong 
commitment to the sorts of epistemologies and ontologies of the schools of analysis we shall see later on: it is a sort of working procedure, inspired by the four basic principle of discourse analysis, and brought off in bespoke ways to make sense of one particular topic or domain of experience. The method of choice in such work is often an inspection of textual material (e.g. news media reports) or interview transcripts (e.g. researchers' interviews with informants chosen for their particular experiences). The author or speaker is not, however, taken to be a simple informant, reporting unvarnished facts; he or she is seen as producing (or reproducing) themes or representations (sometimes called 'interpretative repertoires', after the influential use made of the term, originating in Gilbert and Mulkay, 1984, by Potter and Wetherell, 1987). The job of the analyst is to sift carefully among the material to extract these themes or repertoires, and thus uncover the underlying dimensions along which the author or interviewee makes sense of their experiences, or, if the interest is less psychological, to uncover the imprint that society has left on their lives. Generic discourse analysis is, however, difficult to illustrate with a given empirical example, precisely because different studies take a great deal of colouring from their topic of interest (which might be media reports of political events, or people's experiences of health and illness, or organisational change, or educational practice, to name three typical examples).

We shall be on firmer ground if we turn now to see how particular styles of discourse analysts address the texts in front of them. In what follows, I shan't be able to describe all the varieties of DA that I list in Table 1, still less those which haven't quite yet joined the canon. I have chosen five influential varieties that have been successful (and controversial) in different ways: narrative analysis, critical discourse analysis, interactional sociolinguistics, conversation analysis and discursive psychology. I have also appended a further example to illustrate the sort of ecelectic analysis that borrows from more than one school. I have allocated space to these six according to their influence as I see it, acknowledging that other reviewers may see things differently. Setting them out in series will reveal, I think, that the differences between them are instructive about what is at stake in the discourse analytic project as a whole. 


\section{Narrative analysis}

The origins of narrative analysis lie in literary anatomies of folk stories. Since the publication of Vladimir Propp's The Morphology of the Folktale (1928), folklorists and literary analysts have had an interest in discerning the underlying and possibly universal patterns in what seem to be discrete and individual stories (for example, in one of Propp's most basic templates, the underlying pattern of 'the quest' or 'the restitution of an object lost at the start of the tale'). Social sciencists, as opposed to literary and folklore scholars, have seized on the idea of structure, but shied away from looking for universal primitives as such. Their interest is in finding how the narrator finds a pattern and chronology that makes sense of her or his own unique life and the events in it (see, for example, the work collected in Schiffrin, De Fina, and Bamberg, 2006). Such patterns and chronologies might be shared among a like-minded group, but can equally be wholly particular to the individual.

As illustration we may consider the work of Michelle Crossley, whose Introducing narrative psychology: self, trauma and the construction of meaning (2000) crystallised the application of narrative discourse analysis to the study of psychology, especially the psychology of health and wellbeing. Crossley analyses, among other kinds of narrative, the self-reflections of people who have undergone traumatic changes in their health. Here is an except from such a reflection, in an autobiography:

"Without even realising it, before my diagnosis I had been living in an open, expansive, interior space. Now the walls and ceilings had moved uncomfortably close. Limits were everywhere I looked. . . . Gone was my sense of feeling protected or secure. Gone, too, was any feeling of certainty about the future. As my treatment progressed, these invisible losses were to become more painful, in some ways, than the outward, physical losses and privations of the disease and its remedies." (Mayer, p 54, 1994, cited in Crossley, 2000)

Crossley's analysis points us towards the realisation that in words such as these, we see how psychologically important it is for the individual to have an articulable 'story-line' 
which maintains continuity and integrity: the trauma is destructive insofar as it radically disturbs one's sense of trajectory and sense of selfhood. As Crossley puts it: "This sense is severely disrupted in the face of trauma, which demonstrates a devastating capacity to 'unmake the world'". (Crossley, 2000, p 541). The promise of this sort of discourse analysis is that it will recast 'facts' as constructions, reveal heretofore unsuspected and perhaps marginalised experiences, give voice to those whose experiences are not well understood, and perhaps feed into policy making in the domains of health and education, two areas where narrative analysis has a strong presence.

\section{Critical Discourse Analysis}

The umbrella term 'Critical Discourse Analysis' shelters a broad family of analysts, but all have this in common: they approach texts from a certain prior point of departure, often an avowedly political one. That is the 'critical' in the term. "The way we approach these questions", says van Dijk, one of the doyens of Critical Discourse Analysis, "is by focussing on the role of discourse in the (re)production and challenge of dominance. Dominance is defined here as the exercise of power by elites, institutions or groups, that results in social inequality, including political, class, ethnic, racial and gender inequality."' (van Dijk, 1993, p 249; emphasis in the original). To be aware of the exercise of power, and its resulting social inequality, requires a political theory about social life; and to have such a theory is vital. Otherwise, the CDA argument runs, one risks analysing non-problems or trivialities, or telling only part of the story, and missing its political significance. In the worst case, one's merely technical analysis, by refusing to recognise political forces at work in the data, may implicitly condone or perpetuate them.

Within this broad family of analysts there are those who come from a post-structuralist background, to some degree independent of the linguistics traditions which inform a good deal of critical discourse work. In the post-structuralist tradition much use is made of Michel Foucault's insights into the operation of power in discourses, and, increasingly, psychoanalytical concepts from the school of Jacques Lacan. An example of this sort of critical discourse analysis can be found in the work of Ian Parker (see, for example, his programmatic statement, Parker, 2003), and in the narrative analysis of Wendy Hollway 
(see, for example, Hollway and Jefferson, 2000), among many others. Other critical discourse analysts come from linguistics background, and bring with them an array of linguistic tools with which to unfold their data.

For an illustration of the more linguistically-oriented kind of critical discourse analysis, consider this exemplary analysis, taken from a joint account of CDA by two of its best known (but of course not uniquely representative) proponents and theorists, Norman Fairclough and Ruth Wodak (1997). They give a 125-line long extract from a questionand answer radio interview with Margaret Thatcher during her time as Britain's Prime Minister. It is not an event-led news interview; she is being asked generally, if I can offer a rough gloss, about her political beliefs and aspirations. Fairclough and Wodak present their analysis in eight facets, of which I select the two most emblematic examples. Inevitably this will impoverish what they say, but it will give a flavour of these authors' CDA style, on two central CDA themes: power and ideology. I will quote part of the transcript to help illustrate their analysis.

\section{Extract 1: From Fairclough and Wodak, (1997, pp 269-270). MT = Prime Minister}

\section{Margaret Thatcher.}

61 MT [...] then you turn to internal security

62 and yes you HAVE got to be strong on law and order

63 and do things that only governments can do but

64 there it's part government and part people because

65 you CAN'T have law and order observed unless it's

66 in partnership with people then you have to be strong

67 to uphold the value of the currency and only

68 governments can do that by sound finance and then

69 you have to create the framework for a good

70 education system and social security and at that point

71 you have to hand over to people people are inventive

72 creative and so you expect PEOPLE to create thriving 
industries thriving services yes you expect people

Power. Fairclough and Wodak see Thatcher's display of power in a number of discourse features: her use of longish monologues; her interruption of her interviewer (not illustrated in the extract above); and her use of linguistic devices such as parallel constructions ("it has to be strong to have defence"... "you HAVE got to be strong on law and order"... "you have to be strong to uphold the value of the currency"). Such rhetorical devices, the authors claim, are 'the prerogative of professional politicians' (ibid, p 272). CDA's willingness to use extra-textual claims (in this case, about what generally politicians do) is shared by many, but not all, kinds of discourse analysis.

Using thir knowledge of the political scene, the authors are able to say that by using such privileged talk, Thatcher not only "circumvents and marginalises [the radio presenter's] power as interviewer", but also exercises her power over the radio audience. They go on to observe that "Thatcherism can ... be partly seen as an ongoing hegemonic [power] struggle in discourse and over discourse, with a variety of antagonists - 'wets' in the Conservative part, the other political parties, the trade unions, and so forth" (p 273). This is a good illustration of how CDA is able to make the kind of generalisation that allows it to link the immediate data back to the analysts' prior political commitments.

Ideology. The authors note that, in the extract above, Margaret Thatcher formulates a free-market ideology explicitly; but their analysis aims to adds value by showing how she expresses the ideology more subtly. This stretch of her words (and some 20 further lines not shown here), they say, "is actually" [i.e. not as one might first naively think, without analytic help] "built around a contrast between government and people which we would see as ideological: it covers the fact that 'people' who dominate the creation of 'thriving industries' and so forth are mainly the transnational corporations, and it can help to legitimize existing relations of economic and political domination" (pp. 265-266). 
Fairclough and Wodak do not specify exactly where in the extract Thatcher's failure to mention transnational corporations was significant (that it is a "fact" that her words "cover"). This is an important analytic point. Claiming that something is a fact, and that it is significantly absent from a stretch of discourse, is a harder claim to ground than pointing to something that is significantly present (after all, there is an infinity of things that may be facts, and which are absent from any given stretch of talk or text; whereas what is there is at least there). Different discourse analysis traditions solve the problem in different ways. CDA notices absence not by working it out from the logical or pragmatic implications of the utterances around it, or from of the reaction of those who are there to hear it, as other schools of analysis do. It works it out by virtue of prior theorising about the political or social nature of the world to which the utterance refers. In this case, Fairclough and Wodak have a prior theory or account of what is happening in the British economy, what 'thriving industries' refer to, that these industries are owned by transnationals, and that this ownership is important in the discussion that Thatcher is currently having with her interviewer. They have a further belief, or expectation: that, if given an opportunity, a speaker ought to express the politically relevant facts of the matter (as the analysts see them, and whether they are logically or pragmatically implied or not, or whether the speaker's local interlocutors hold them to it or not). Margaret Thatcher was given the opportunity, and did not mention transnationals; therefore, it is analytically safe, as well as useful, to claim that she is masking their role in the economy.

If we translate these snippets of analysis back into the four core features of DA (data found naturally; interpreted in co-text; non-literally understood; actions achieved), we see that CDA will insist on a very wide sense of "co-text" in its interpretation, and on drawing out implications which may not be visible to those who do not share the analyst's prior political commitments, or hesitate to apply them to the data. Its prime candidate for "social action" is the action, taken to be unequally shared in society, of constituting the social world. CDA is attractive to scholars who have the view that discourse analysis must ally itself to a social theory, and must be aware of inequalities in society. This is shared, in a more dilute form, in the next influential discourse analysis I shall look at. 


\section{$\underline{\text { Interactional Sociolinguistics }}$}

Interactional sociolinguistics emerged from quantitatively-minded variation sociolinguistics of the 1960s (and which still continues today) which sought to correlate features of speech (like a glottal stop or a truncated verb form) with demographic factors like geographic location or socioeconomic class, or situational variables like the formality or informality of the speech setting. As interest shifted into what those features of speech might actively be doing in interaction, researchers dropped the survey method in favour of a close qualitative look at what was going on in the scene - what the founders of interactional sociolinguistics, Dell Hymes and John Gumperz, called the 'ethnography of communication'.

Like Critical Discourse Analysis, interactional sociolinguistics means to explore the way that social and cultural forces (including power differentials) cash out in the details of talk. Unlike CDA, its proponents do not normally require a specific prior theory of politics or society, beyond a generic belief that society is structured along class, gender and cultural or ethnic lines, and an expectation that this structure will reveal itself in interaction. A further difference is interactional sociolinguistics' preference for a great deal of ethnographic knowledge of the local scene in which the discourse takes place, and a fairly particular set of codes with which to analyse it.

To the degree that working interactional sociolinguists draw on pioneering work by John Gumperz, they will see people achieving their local goals (or being thwarted from doing so) by offering each other (and taking up, or failing to take up) 'contextualisation cues'. These are various sorts of hints, codes and signals as to what speakers mean. (The requirement to call such things 'contextualisation cues' has been progressively relaxed as interactional linguistics becomes more widespread, but remains important for core proponents of the method.) To get a sense of what these contextualisation cues are doing, the interactional sociolinguist is committed to knowing something about the local ethnography of the speakers' situation: what jobs they do, what their goals are and so on. 
Here is an illustrative analysis, taken from an account meant to show off interactional sociolinguistics against a number of other discourse approaches (Stubbe et al, 2005). Before turning to the transcribed recording, the authors give us some background:

"The discussion takes place between a senior public service manager, Tom, and an analyst, Claire, who is two ranks below him in the organisational hierarchy. From the ethnographic fieldwork that was done at the time of the data collection, we know that Claire is annoyed that she was overlooked for the shared acting manager position she believes she was promised by her own manager, and that she and some of her female colleagues interpret this as another example of gender discrimination within the organisation. We also know that she has expressed the intention to raise the issue with Tom [...continues ...]" (Stubbe et al. p 359).

The authors then invite us to read over the following lines to see how Claire gets across to Tom a way of framing what she is about to say or do in the interaction:

Extract 2: From Stubbe et al p 381 (transcription conventions in this extract: "+ " is a pause of up to one second; sloping lines indicate overlapping speech)

$<\# 1: C T>$ yeah um yeah i want to talk to you about um oh it's a personal issue $u m+$ well $\mathrm{i}$ - the decision to make um jared acting manager while //joseph $\backslash$ is away

$<\# 2: \mathrm{TR}>/ \mathrm{mm} \backslash$

The authors point to certain speech features (the intonation, the ums, the false starts) that suggest that Claire is nervous. The interactional sociolinguist means to ask why this might be so in this local scene, and what it might prefigure for the conduct of the interaction, We can infer, the authors tell us, that one cause of her nervousness is the fact that she is lower in the hierarchy than is her interlocutor (something they have established prior to this recording). Furthermore, she is nervous because she is doing what women do 
not do: "she is behaving in a direct, competitive way which is not stereotypically associated with women. This may help to explain some of the apparent tension in itself, as well as the likelihood that, given that her addressee is a senior male, her utterance may be heard as an implicit accusation of gender bias.." (ibid p 360). So the interaction starts off with the 'contextualisation cues' of a complaint involving gender bias, and the authors can then proceed to see how these two interlocutors bring it off.

Interactional sociolinguistics' version of the four core features of DA (data found naturally; interpreted in co-text; non-literally understood; actions achieved) gives generous place to the wider ethnographic context. It is willing to use information from prior scenes to guess at what participants are feeling and intending in this one. It admits into its analysis inferences from prior theories, or common assumptions, about interaction. In the extract above, for example, a speaker was judged to be 'nervous', and her nervousness was partly ascribed to a common-sensical fear that a woman risks being heard as making a gender-based complaint. Such theorising is less particular and explicit than is required by CDA, yet still contrasts starkly with Conversation Analysis' distaste for what they consider to be 'going native'.

\section{Conversation Analysis}

Conversation analysis (henceforth, CA) is the study of social action as achieved through the medium of talk in interaction. Its genesis was in the dissatisfaction of some sociologists in the late 1960s with the dominant quantitative methodologies of their discipline, which were silent about how people actively realised the social world, in real time. In the forty years since the pioneering work of the group around Harvey Sacks (whose lectures were published posthumously as Sacks, 1992), CA has attracted a good deal of attention within sociology and outside it, and has developed into a multidisciplinary enterprise (for an account of the history of Conversation Analysis, see Heritage 1984; for a more recent overview of its methods and style, see Hutchby and Wooffitt, 1998; and for an account of its relation to other modes of discourse analysis, see Wooffitt, 2005). 
CA abides by the four generic DA criteria of looking for natural data, setting it in its cotext, watching for its non-literal meaning, and identifying the social actions performed. Perhaps its most obvious departure from this basic platform is its insistence on seeing social actions done though the very close organisation, as well as the content, of talk. In describing those actions, CA - again unlike generic DA - wants to stay as close as possible to the speakers' own understandings of the actions without imposing interpretation from above or speculation about motives from below. Its 'added value' is teasing out the what and the how, while shying away from the why, and leaving off anything not made 'live' by the participants in the scene.

The currency that CA trades in might be structures on a chronologically minute scale (for example, the binding relation between speakers' adjacent utterances, and the injunction to keep their separation brief) or extensive (the overall shape of a story delivered over many turns), but they are all normative. That is to say, speakers are expected to follow them, or risk (or invite) listeners to draw implications when they do not. We can see an example of such a normative structure in the simple example below, where the second utterance meets the expectation of a prompt acceptance of the first:

Extract 3: Holt:1988 Undated: Side 2: Call 1 (original transcription much simplified; for full list, see appendix)

1 Les: ((material not shown)) now we're feeling a bit freer.

$2 \quad$ (.)

3 Arn: [Y $\underline{\text { Ye:s. }}$

4 Les: [.hhhhhh So we wondered if you'd like to meet us.hh

$5 \rightarrow$ Arn: $\underline{\text { Yes certainly. }}$

To show how strong the normative expectation is that the response be positive and prompt, consider this variant. Here the speaker's non-normative silence in line 3 invites the listener to draw a significant implication. 
Extract 4: From Levinson (1983), p 320

1 A: So I was wondering would you be

2 in your office on Monday (.) by any chance

$3 \rightarrow \quad(2.0)$

4 A: Probably not.

Note that it is A who is responsible for both turns - so why does s/he answer his or her own question, and answer it with a negative? Because B has done the unexpected thing of not answering, and thus allowed the implication that the answer is 'no'. A then makes plain that this has been understood. The interaction can proceed, with both parties now having disposed of the possibility that A visit B's office on Monday, without A having had explicitly to say no. The 'action' has been achieved by exploiting of the regularities of talk.

CA has been applied productively to a variety of institutional activities otherwise accessible only in retrospect (by interviews with participants) or in simulation, or through comparatively coarse contemporary observation. For example, CA has been used in research on how talk in interaction achieves business meetings (Boden, 1994), educational testing (Maynard and Marlaire, 1992) and survey interviewing (HoutkoopSteenstra, 2000), to take a few notable examples.

What can CA reveal about such working interactions? Peräkylä and Vehviläinen (2003) put it neatly. Members of a trade or profession (they were talking about psychotherapists, but it's true of anyone who routinely has dealings with clients) may have "stocks of interactional knowledge" -fairly clear ideas of what they do with the people they work with. CA can check these accounts, correct them, or go beyond them. In going beyond lay accounts, CA can discover things about the interaction that the practitioners didn't suspect, or which have effects or functions which don't figure in (or indeed may be counter to) the official aims of the encounter. 
As an example of CA's illumination of professional practice, consider Maynard's work on clinicians' delivery of a diagnosis. He inductively finds a pattern in which the clinician prefaces the actual diagnosis (you have $X$ ) by evidence (from test results, and so on). The typical sequence is like this, in which a doctor in a Developmental Difficulties clinic is talking to a mother about her five year-old son:

\section{Extract 5: From Maynard (2004, p 63)}

1 Dr Y: From the:: test results (0.3) he seems to function (0.6)

2 comfortably (0.2) you know and (achieve) some kind of you

3 know happy and responsive

$4 \quad(0.2)$

5 Mrs R: Ye [e:s ]

6 Dr Y: $\quad$ [.h ] ]hh ON THE LEVEL of about you know three (0.1) and $7 \quad$ a half year old child

$8 \quad$ Mrs R: $\mathrm{mm}$

The doctor is describing evidence: the boy seems to function comfortably at the level of a three and a half year old. She is not (yet) giving a diagnosis. The next extract follows the first (though some intervening talk has been omitted). But notice how the doctor manages to avoid actually stating the child's condition even as she makes her recommendation.

\section{Extract 6: From Maynard (2004, p 63)}

1 Dr Y: I feel very strongly that, you know, because he (0.4) tests

2 some kind you know, functions between mildly retarded and

3 borderline level [.hhhhh ] ]he needs special class placement.

4 Mrs R: $\quad[\mathrm{Mm} \mathrm{hmm}]$

$5 \quad$ Dr Y: (Yeah) the (.) class for (0.2) .hh educable mentally retardet

$6 \quad$ (0.2) will be the best (.) for his (0.8) you know?

7 functioning and emotional, he's still not ready you know

8 enough [to be more- ]

$9 \rightarrow$ Mrs R: $\quad$ [Are y- are you tr] 
11 Dr Y: [Yes.]

What the doctor has done is to glide from a statement of the evidence (from the tests) to a recommendation for treatment, passing over actually naming the child's condition. It falls to the mother (at line 9) to make explicit what has so far been implicit. Maynard has noted this pattern in his work on news delivery in mundane conversation (Maynard 2003). The news deliverer organises their hints at bad news in such a way that it is the recipient who is prompted actually to pronounce it. In ordinary social life that hinting has a set of implications which we might interpret as being to do with the complexities surrounding death and other taboo issues; in the clinic, it has all those, but also has more prosaic consequences as well. If the patient (or their representative, as in the case above) is the one who comes out with the news, it shows that he or she has been attending to what the doctor said, at least enough to work things out for themselves; it puts patient and doctor on something of an equal footing. Certainly it is more equal (or more equallooking) than would be the case if the doctor simply pronounces the condition straight off.

\section{$\underline{\text { CA and "Membership categories" }}$}

My account of Conversation Analysis so far has focussed on sequential analysis. There is another strand of CA, traceable back to Sacks' work in the early seventies, which, although it is alive to sequence and placement of utterances, is concerned with them insofar as they sustain the speaker's version of events; and specifically, the speaker's choice of identity or person categories. This is sometimes called Membership Category Analysis (though many in CA prefer to see it as merely a part of the broader CA project); but in any case, it is very different from other discourse work on identities. A generic discourse analysis of identities would look at material which explicitly names a given identity category (say, "asylum seeker"), and chart the ways in which that category is constructed. The aim of that sort of analysis would be to draw up a picture of "asylum seeker" as it appears, explicitly and subtly, in the materials. Then a further stage of analysis takes over, and speculation is made about what interests such a picture serves in 
a general way in society. For CA, there is no need to go to such an abstract level and separate the use of the category from its consequences. The speaker or writer's use of (or hint at) an identity category is locally effective. If you call someone an asylum seeker (or hint that she or is one) then you are doing it for local consumption, and the consequences will be interactionally visible. And this is true for mundane categories (like, say, "daughter") as much as it is for more politically-charged ones.

In the case of politically-charged identities, consider what is happening here, in this extract from Dennis Day (Day 1998)'s account of 'ethnification'. Here, some workers in a factory in Sweden are in a coffee break and planning an upcoming works party.

\section{Extract 7: Day, 1998 p 163 (English translation from the Swedish)}

1 L: that one has wine and normal drinks too,

2 right, of course like a party

$3 \quad$ ((writing))

$4 \rightarrow \mathrm{L}$ : that's what we have at least here in

$5 \rightarrow \quad$ Sweden one drinks wine, that's of course

6 what [one wants

$7 \quad \mathrm{R}: \quad$ [of course, it's like different that

$8 \quad$ [to drink

9 L: [what does one drink in what does one

10 drink

11 L: ((points))

$12 \mathrm{X}$ : [don't drink wine but light beer or just (soda)

Speaker "X", Day tells us, is categorisable on sight as not ethnically white-Swedish; she is (or looks) Chinese. But notice that we hardly need even this minimal piece of ethnography (and the reader might compare it with the thick description and inference required by interactional sociolinguistics; see above). See how, in line s 4 and 5, it is one of the participants himself (L) who introduces the notion that Otherness is a live issue. That's what (drink) we have, he says; at least here in Sweden one drinks wine. It is the 
'we' and the 'here in Sweden' that do the work of setting national or ethnic identities on the table. From the CA point of view, the minimal observation is that $\mathrm{L}$ has 'ethnified' $\mathrm{X}$ to the extent that he has called into question what drinks should be made available at the staff party. But there is more. He has explicitly excluded X from "we ... here in Sweden". The effect is to exclude her not only from the fellow-national category but the locally operative category of fellow member of the current social group.

Both Day's work, and that of Maynard that I described above, are examples of CA's claim to deliver the substance of large-scale social phenomena. Their claim is that if we want to say that, for example, agreement between patient and clinician is at a premium in US consulting-rooms; or that people can exclude fellow-workers from joint ventures by subtly casting them into ethnic categories; then CA will provide the evidence unaffected, its adherents say, by prior theorising about context or social forces.

\section{Discursive Psychology}

The epistemological commitment of conversation analysis - to begin with what the participants in the scene make visible to each other - is shared by Discursive Psychology. This is a movement, impelled by a number of hands, to make Psychology treat the traditional psychological topics of perception and cognition (seeing, remembering, knowing and so on) not, in the first place, as mental and individual matters, but as resources that people use: a person will avow a belief, challenge another's veracity, test a third person's knowledge, admit a faulty memory, and so on. This branch of Discourse Analysis, like others we have covered, comes in various versions. I will pick an illustrative example from what has probably been the most empirically productive form, the Discursive Psychology developed by Derek Edwards and Jonathan Potter (for programmatic statements of their project, see Edwards 1997, Edwards and Potter 1992, and Potter 2003).

Consider Edwards' work on emotions (see, for example, Edwards, 1999). At first sight, emotions find a natural home in traditional Psychology: they are (surely?) subjective, directly experienced, irrational, stimulated by events in the world, and liable to vary in 
intensity and character according to classic psychological variables such as social and physical stimuli, mood, age, gender and so on. Yet, Edwards argues, to say all this is to put the cart before the horse. All these things are true not necessarily about emotions-inthe-head, but about emotions-as-traded-in-interaction. People (who, after all, predate psychologists) treat them as all of the above things, and psychologists have fallen into the trap of thinking they are all true. Edwards does not mean we should therefore replace a scientific study of emotions with a study of people's folk-theories about emotion, or by asking them survey questions about what they think emotions are, or by recording their spontaneously offered definitions of emotions in natural talk and so on. Such things are of secondary importance. What is of prime importance is how people bring emotion terms into conversations (which may be mundane chat, or consequential events like police interrogations, marital counselling, psychotherapy, courtroom testimony and so on) actually to achieve their ends. To be sure, such ends will be served by the presumption that an emotion is internal, not rational and so on and so forth (or some distortion of this list, as circumstances demand) but that in no way guarantees the truth of the presumption, still less persuade us to give up the study of emotions in talk in favour of a possibly chimerical survey of emotions in the head.

We can put flesh on that argument by looking at a stretch of talk that Edwards reports from a marital therapy session, where one person's descriptions of their spouse's emotions have, of course, a high premium. Early in the session, 'Mary' describes what happened when she told her husband 'Jeff' of an affair she had had:

\section{Extract 3 (DE-JF:C1:S1:4)}

$\begin{array}{lll}1 & \text { Mary: } & (. .) \text { so that's when I decided to (.) } \\ 2 & & \text { you know to tell him. (1.0) U::m (1.0) } \\ 3 & \text { and then::, (.) obviously you went } \\ 4 & \text { through your a:ngry stage, didn't you? } \\ 5 & \text { (.) } \\ 6 & \text { Ve:ry upset obviously, .hh an:d uh, } \\ 7 & \text { (0.6) we: started ar:guing a lot, an:d } \\ 8 & \text { (0.6) just drifted awa:y. }\end{array}$

Edwards invites us to notice how Mary trades on the presumptions of emotion-terms to accomplish a number of rhetorically powerful moves. Jeff's reaction to Mary's revelation 
was (according to her account) to be angry, she does not report his state of mind as a matter of reasoned appreciation, but of visceral reaction. Moreover she portrays this anger as your angry stage. This implies that Jeff is prone to a predictable chain-reaction of emotions that are sparked, then run their course. These two undercurrents, heavily implied but never stated, bear Mary's narrative into the rhetorically clear waters of inevitable separation. As Edwards puts it:

"... while Jeff's anger is proper in its place, one would not expect it to go on forever, to endure unreasonably, beyond its 'stage'. Mary has made rhetorical room for something she goes on to develop, which is the notion that Jeff's reactions are starting to get in the way of progress, starting to become (instead of her infidelity, as Jeff insists) 'the problem' they have in their relationship. Indeed, the next thing she says in her narrative (and implicationally, therefore, what not only follows but follows from Jeff's reactions) is how 'we started arguing a lot, and just drifted away' (...) Their problems are now joint ones, arguments, and a kind of non-agentive, non-blaming, ‘just’ drifting apart." (Edwards, 1999, p 277)

In other words, Mary's description of events, in just that way and at just that time, has socially important consequences for how her relationship is to be read, how her spouse's role in proceedings is to be understood, and perhaps how the counselling will proceed. Deploying an emotion term was not a neutral matter of describing the world as it is and was, but a rhetorically-charged choice of a term that packed a punch, as any choice of description always does.

Edwards' analysis here of the emotion term angryis a good example of the respecification that Discursive Psychology intends for the entire realm of 'the mental'. It reminds psychologists that emotions, like any other ostensibly mental state of mind, may be allegedly owned in private, but are manifestly traded in public. This makes Discursive Psychology specially attractive for application to any discourse in which play is made of psychological terms, and that of course is a wide field. But we should notice that Discursive Psychology is not limited to the study of the use of psychological terms, common though such usage is. One consequence of its radically anti-cognitive strand is that it puts it four-square with other discourse analyses which see discourse as 
constitutive of social (and not just social) reality - see, for example, Potter's Representing Reality(1996). Were space to permit, it would have been instructive to describe its close, ethnomethodologically- and Conversation Analytically-inspired investigation of people's interested descriptions and accounts of events, for example in such charged encounters as the police interrogation (Edwards, 2006). In its concern for unpacking descriptions of reality, Discursive Psychology is applicable to discourse in its widest remit.

\section{An example of an eclectic Discourse Analysis}

I want to turn for my last example to a discourse analysis inspired - if distantly - by ethnomethodology. If ethnomethodology has a place in a survey such as this one, it is an uncomfortable one at best. Most practitioners of ethnomethodology would not describe themselves as doing discourse analysis. Their aim - as the term 'ethno-methodology' suggests - is to explicate the reasoning practices or rules that ordinary people display in prosecuting their ordinary lives. While some of those practices are made visible in their use of language, many others are embodied in the props and resources which furnish the daily scene; in the temporal organisation of people's comings and goings; in the artefacts and documents available for people to consult or refer to; and in the affordances of the physical sites they live and work in. Thus if one wanted to find out how people solve the problem of (say) taking turns to be served (Garfinkel, 2002 ch 8), one would not limit oneself to analysing people's language, but would analyse the ebb and flow of bodily movement, synchronised occupation of space, gestures, gaze and so on, to see how queues form and are oriented to and policed. Much more than language needs to be mastered by the person who wants competently to join a line for service - as many of us who have tried the experience in unfamiliar places, perhaps when in foreign lands, can testify.

Nevertheless, ethnomethodology has inspired a kind of discourse analysis which, while wanting to explicate people's public reasoning processes, privileges talk in its ethnographic setting. Perhaps the best label for such work is 'eclectic', since it combines the four canonical principle of discourse analysis with a concern for the physical and temporal location in which the event takes place. For an example of such work, I have 
chosen a much-anthologised study by Hugh Mehan (1996) on how children are sorted into various categories by educators. This picks up the theme of identities in the section on CA above, and shows how an eclectic discourse analyst can use non-talk elements of the scene.

Mehan follows the career of one nine-year old boy ("Shane"). Our first sight of him is when a teacher spots him behaving in a way that concerns her. He then becomes a case for the educational psychologist, who tests him, and the language in which he is described changes from the teacher's common-sensical, teacherly talk ("he's very apprehensive about approaching anything..." .."whenever he's given some new task to do it's always like, too hard, 'no way I can finish it"') to technical, quantitative norm-based terms ("he was given the WISC-R and his IQ was slightly lower, full scale of 93...").

Mehan's set-piece for analysis is a recording of a subsequent meeting of educators (teachers, educational psychologists and so on) and parents. At this point Shane's fate, as is that of a list of children who have to come to the school's attention as possibly needing special education, is to be decided. Each case will be decided by talk; and as the outcomes are quite dramatically different (the child might be classified then and there as "learning disabled" and sent to one kind of school, or as "educationally handicapped" and sent to another), the power of discourse is all too visible.

It is up to the Board to hear the various descriptions of Shane available from his teacher, his parents, the school nurse and the psychologist, and meld them into a decision as to just what kind of schoolboy he is. Mehan describes the props (for example, the psychologist's thick bundle of forms, test scores and reports) or the lack of them (the child's mother has no notes) as part of the action. The props round out his observations about the talk: that, for example, the psychologist refers to her official notes while delivering her account uninterrupted, while the mother's unsupported account is drawn out by others' questioning; or that the psychologists' document-based story, although freighted with obscure jargon, is not challenged, whereas the mother is asked to explain what she means by her common-sense claims about her son's behaviour (claims that 
would pass unremarked in a more mundane setting; for example, that "lots of times he comes home and he'll write or draw"). Mehan 'adds value' of a startling kind when he claims that

\author{
"The psychologist's report gains its authority by the very \\ nature of its construction. The psychologist's discourse \\ obtains its privileged status because it is ambiguous, \\ because it is shot full of technical terms, because it is \\ difficult to understand" (p 357; emphasis in original)
}

Mehan's point is that the technicality of psychologist's claims meant that they could not easily be challenged, so her conclusions were never subject to the sort of test that the mother's or the teacher's could be. Because of its permitted obscurity, it is the psychologist's report that carries the day, and Shane is classified as having a learning disability; he has been set on a career which may have profound consequences (for good or ill). Mehan has not simply noted that different sorts of evidence have been brought forward to reach this decision; by careful note of how descriptions are phrased and received he has offered us the analysis that (as he puts it) "these modes of representation are not equal" ( $p$ 356). It is a discourse analysis that delivers the generic promise not merely of describing talk but of explaining social action, and adds specific ethnomethodological value by charting participants' treatment of each other and the distributions of powers and expertise that they allow themselves.

\title{
Concluding Comments: Discourse analysis means doing analysis
}

A word is in order to remind the reader that this account of discourse analysis has been selective. Each example, in the sections above, elbowed its way past a dozen equally significant competitors. Some styles of analysis were crowded out entirely, and a longer chapter may well have found space for interpersonal phenomenological analysis (Smith, 2004), psychoanalytically-oriented Marxist critical discursive psychology (Parker, 2002); Foucauldian discursive psychology (Wetherell \& Edley 1999); free-association narrative inquiry (Hollway and Jefferson, 2000); and action-implicative discourse analysis (Tracy 
2005), among others. And I ought to say that many working discourse analysts claim no specific rules beyond the four canonical DA features of looking for social action in natural data, non-literally understood in its co-text. Indeed some discourse analysts have made an explicit virtue of keeping their independence from restrictive technicality. An eloquent defence of this way of thinking is Billig's case in favour of critical scholarship over narrow method (Billig, 1988, 1999). It is better, on his argument, to have the core discourse analytic sentiments in mind, be guided by a critical spirit, and to avoid particular methodological practices which might miss as much as they catch.

However, whether one flies under the flag of a particular kind of discourse analysis or sails alone, it is not the case that "anything goes". The editor of one of the principal, indeed defining, journals of the field sounds a clear warning in his editorial instructions: "Articles should provide a detailed, systematic and theoretically based analysis [...]. It is insufficient to merely quote, summarise or paraphrase such discourse" (Teun van Dijk, in the instructions on 'Preferred Papers for Discourse \& Society' which has appeared in the journal since March 2002). A useful expansion of that injunction can be found in a joint paper by Antaki, Billig, Edwards and Potter (2002) who, although as individual authors vary in their theoretical allegiances, nevertheless insist together that, as they put it, 'discourse analysis means doing analysis'. Any discourse analyst who claims to be analysing, they argue, must 'add value' to what is readable or hearable in the words straight off, beyond simple paraphrasis or glossing; they must be able to back up their claims with some evidence grounded in the words used or warrantably not used; and they must reach their conclusions by argumentative steps available to a fair-minded fellowscholar.

To use a discourse analysis 'method', or not, and which method to use, is not a simple matter of bloodless fashion; there are strong forces at work which push new methods onto the agenda (and indeed resist them). I haven't been able to do justice to such forces in this chapter; for an excellent recent survey of the general ebb and flow in the tides of discourse methods, see de Beaugrande's useful short account (de Beaugrande, 1997), Wood and Kroger's book-length overview (Wood and Kroger, 2000) and Denzin and 
Lincoln's thoughtful introduction to their recent Handbook of Qualitative Research (2005). Discourse analysis is a particularly unsettled method of working in the social sciences - probably because, to its adherents, who want to understand (and sometimes unmask) social action, the stakes are high. 


\section{Further Reading}

The sources cited in the References (at the end of this chapter) will take the reader further along the particular paths sketched out in the text. Those who would like to follow up issues and topics I have only mentioned glancingly may like to pick among the following further readings.

\section{Interpersonal Phenomenological Analysis}

An approach to individual meaning-making through a discursive analysis of interviews.

Smith, J.A. (2004) Reflecting on the development of interpretative

phenomenological analysis and its contribution to qualitative research in psychology. Qualitative Research in Psychology, 1, 39-54.

\section{Feminist Discourse Analysis}

For a variety of examples of discourse analytic research projects that offer a specifically feminist approach, see:

Lazar, M. (Ed.) (2005). Feminist Critical Discourse Analysis: Gender, Power and Ideology In Discourse. Basingstoke: Palgrave.

\section{Varieties of Critical Discourse Analysis}

There is broad range within Critical Discourse Analysis. These sources, along with those cited in the text, will give an indication of the variety.

Rogers, R. (Ed.) (2003). An Introduction to Critical Discourse Analysis in

Education. Mahwah, NJ: Lawrence Erlbaum.

Toolan, M. (Ed.) (2002). Critical Discourse Analysis: Critical Concepts in

Linguistics (Vols I-4). London: Routledge.

Wodak, R. \& Meyer, M. (Eds.) (2001). Methods of Critical Discourse Analysis.

London: Sage.

van Dijk, T. (1993) 'Principles of CDA', Discourse and Society, $\underline{4}$, pp249-83. 


\section{Debate between Conversation Analysis and Critics}

This exchange is often cited as a useful crystallisation of the debate - not always

temperate - between Conversation Analysts and their discourse-analytically minded critics. I list the papers in their chronological order.

Schegloff, E. A. (1997) 'Whose text? Whose context?’, Discourse and

Society, $\underline{8}$, pp165-87.

Wetherell, M. (1998) 'Positioning and interpretative repertoires: conversation analysis and post-structuralism in dialogue', Discourse and Society, $\underline{9}$, pp387-412

Schegloff, E. A. (1998) 'Reply to Wetherell', Discourse and Society, $\underline{9}$, pp413-6.

Billig, M. (1999) 'Whose terms? Whose ordinariness? Rhetoric and ideology in Conversation Analysis', Discourse and Society, 10, pp543-558.

Schegloff, E. A. (1999) “'Schegloff's texts” as "Billig’s data”: a critical reply', Discourse and Society, 10, pp558-72.

Billig, M. (1999) 'Conversation Analysis and the claims of naivety', Discourse and Society, 10, 4, pp572-6.

Schegloff, E. A. (1999) 'Naiveté vs. sophistication or discipline vs. self-indulgence: a rejoinder to Billig', Discourse and Society, 10, pp577-82

Kitzinger, C. (2000) ‘Doing feminist conversation analysis’, Feminism and Psychology, 10, pp163-93. 


\section{$\underline{\text { References to sources cited in the main text }}$}

Antaki, Charles, Billig, Michael, Edwards, Derek \& Potter, Jonathan (2003). Discourse analysis means doing analysis: a critique of six analytic shortcomings. Discourse Analysis On Line, 1(1). Available at:

<http://www.shu.ac.uk/daol/articles/v1/n1/a1/antaki2002002.html>

Billig, M (1988) Methodology and scholarship in understanding ideological explanation. In C. Antaki (1988) Analysing Everyday Explanation: A Casebook of Methods. London: Sage

Billig, M., 1999, "Whose terms? Whose ordinariness? Rhetoric and ideology in conversation analysis", Discourse and Society, 10, pp.543-558.

Boden, D (1994) The Business of Talk. Oxford: Polity

Chouliaraki, L and Fairclough, N (1999) Discourse in Late Modernity: Rethinking Critical Discourse Analysis. Edinburgh: Edinburgh University Press.

Crossley M L. (2000) Narrative Psychology, Trauma and the Study of Self/Identity. Theory \& Psychology, Vol. 10, 527-546

Denzin, N.K., \& Lincoln, Y. (2005). The discipline and practice of qualitative research. In N.K. Denzin \& Y. Lincoln (Eds.), The Sage handbook of qualitative research. London: Sage.

de Beaugrande, R (1997) The story of discourse analysis. In T. van Dijk (ed) Discourse as Structure and Process. London: Sage pp 35-62

Edwards, D., 1997, Discourse and Cognition, London: Sage 
Edwards, D (1999) Emotion discourse. Culture and Psychology, 5, pp 271-291

Edwards D (2006) Discourse, cognition and social practices: the rich surface of language and social interaction. Discourse Studies, $\underline{8}$, 41-49

Edwards, D and Potter, J (1992) Discursive Psychology. London: Sage

Fairclough, N and Wodak, R (1997) Critical Discourse Analysis. In T. van Dijk (ed)

Discourse Studies A Multidisciplinary Introduction, Volume 2: Discourse as Social Interaction. London: Sage

Garfinkel, Harold (2002) Ethnomethodology's Program: Working Out Durkheim's Aphorism. Edited and Introduced by Anne Rawls. Lanham, MD: Rowman \& Littlefield Heritage, J. (1984) Garfinkel and ethnomethodology. Cambridge: Polity Press

Hollway, W. and Jefferson, T. (2000) Doing Qualitative Research Differently: Free Association, Narrative and the Interview Method, London: Sage.

Houtkoop-Steenstra, H (2000) Interaction and the standardised survey interview: The living questionnaire. Cambridge: Cambridge University Press.

Hutchby, I and Wooffitt, R (1998) Conversation Analysis. Oxford: Polity Press.

Levinson, S. C. (1983). Pragmatics. Cambridge, UK: Cambridge University Press.

Mayer, M. (1994). Examining myself: One woman's story of breast cancer treatment and recovery. Winchester, MA: Faber \& Faber.

Maynard, D W (2003) Bad News, Good News: Conversational Order in Everyday Talk and Clinical Settings. Chicago \& London: University of Chicago Press.

Maynard, D W (2004) On Predicating a Diagnosis as an Attribute of a Person. Discourse Studies, $\underline{6}, 53$ 
Maynard, D W and Marlaire, C (1992) Good reasons for bad testing performance: the interactional substrate of educational testing. Qualitative Sociology, 15, 177-202

Mehan, H. (1996) The construction of an LD student: A case study in the politics of representation. In M. Silverstein and G. Urban (eds) Natural Histories of Discourses. Chicago: University of Chicago Press. Reprinted in M. Wetherell, S. Taylor and S. Yates (2001) (eds) Discourse Theory and Practice. London: Sage Publications.

Parker, I (2002) Critical Discursive Psychology. London: Palgrave

Parker, I. (2003) 'Psychoanalytic narratives: Writing the self into contemporary cultural phenomena', Narrative Inquiry, 13 (2), pp. 301-15.

Potter, J (1996) Representing reality. London: Sage.

Potter J (2003) Discursive Psychology: Between Method and Paradigm. Discourse \& Society, $\underline{14}$, 783-794

Potter, J and Wetherell, M (1987) Discourse and Social Psychology, London: Sage Sacks, H (1992) Lectures on Conversation (Vols 1 and 2) Oxford: Basil Blackwell.

Schiffrin, D., De Fina, A., \& Bamberg, M. (Eds.) (2006). From talk to identity: Methodological and theoretical issues in identity research. Cambridge University Press.

Stubbe, M., Lane, C., Hilder J., Vine E., Vine B., Marra M., Holmes J., \& Weatherall, A. (2003) Multiple Discourse Analyses of a Workplace Interaction. Discourse Studies, $\underline{5}$, 351-388 
Tracy, K. (2005). Reconstructing communicative practices: Action-implicative discourse analysis. In K. Fitch and R. Sanders, Handbook of Language and Social Interaction (pp. 301-319). Mahwah, NJ: Lawrence Erlbaum.

Wetherell, M and Edley, N (1999) Negotiating Hegemonic Masculinity: Imaginary Positions and Psycho-Discursive Practices. Feminism \& Psychology, 9, 335-356

Wood, L A and Kroger R O (2000) Doing Discourse Analysis. Thousand Oaks: Sage Publlications.

Wooffitt, R (2005) Conversation Analysis and Discourse Analysis. London and New York: Sage. 


\section{Transcription Symbols for the Conversation Analysis extracts}

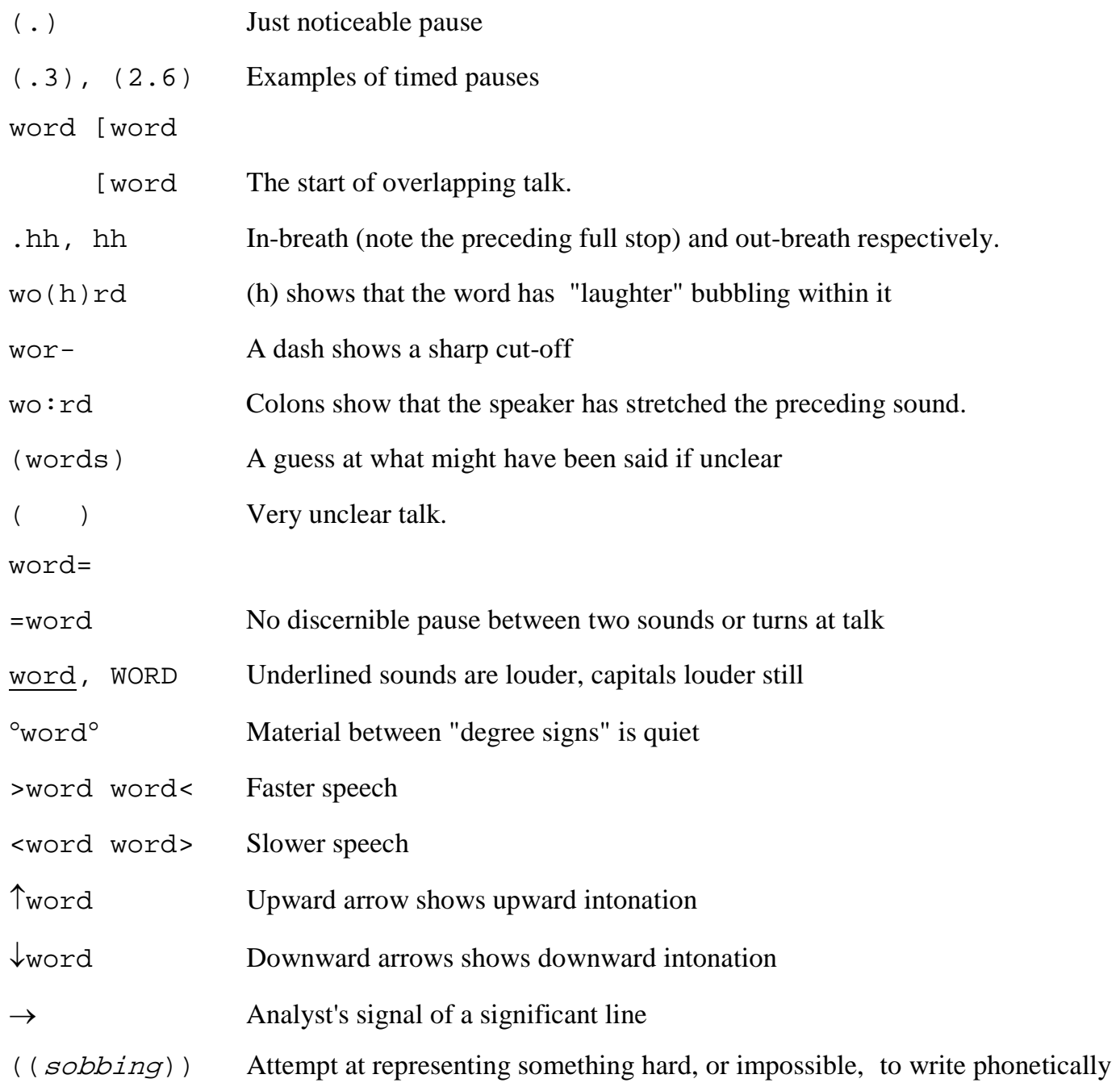

